\title{
Evidence for multiple-insecticide resistance in urban Aedes albopictus populations in southern China
}

Yiji Li ${ }^{1,2,3}$, Jiabao Xu' ${ }^{1}$ Daibin Zhong ${ }^{4}$, Hong Zhang ${ }^{1}$, Wenqiang Yang ${ }^{1}$, Guofa Zhou ${ }^{4}$, Xinghua Su', Yang Wu', Kun $\mathrm{Wu}^{1}$, Songwu Cai ${ }^{5}$, Guiyun Yan ${ }^{1,4^{*}}$ and Xiao-Guang Chen ${ }^{1 *}$

\begin{abstract}
Background: Aedes albopictus (Skuse) is an invasive mosquito that has become an important vector of chikungunya, dengue and Zika viruses. In the absence of specific antiviral therapy or a vaccine, vector management is the sole method available for reducing Aedes-induced disease morbidity. Determining the resistance status of Ae. albopictus to insecticides and exploring the resistance mechanisms is essential for future vector control planning.

Methods: Aedes albopictus larvae and pupae were sampled from six sites (two sites each from urban, suburban and rural) in Guangzhou. The resistance bioassays were conducted against Bacillus thuringiensis israelensis (Bti): deltamethrin, propoxur and malathion for larvae; and deltamethrin, DDT, propoxur and malathion for adults. P450 monooxygenase (P450s), glutathione S-transferase (GSTs) and carboxylesterase (COEs) activities of adult mosquitoes were measured. Mutations at the knockdown resistance $(k d r)$ gene were analyzed, and the association between $k d r$ mutations and phenotypic resistance was tested.

Results: Adult bioassays revealed varied susceptibility against DDT, deltamethrin and propoxur in the six Ae. albopictus populations. Significantly lower mortality rates were found in urban populations than suburban and rural populations. Urban mosquito populations showed resistance against DDT, deltamethrin and propoxur, while one rural population was resistant to DDT. All populations tested were susceptible to malathion. Larval bioassays results indicated that all populations of Ae. albopictus were sensitive to the larvicide Bti and malathion. Resistance to deltamethrin and propoxur was common in larval populations. The F1534S and F1534 L mutations were found to be significantly associated with deltamethrin resistance. Biochemical assays indicated elevated detoxification enzyme activities in the field mosquito populations.
\end{abstract}

Conclusions: Aedes albopictus populations in Guangzhou, especially in urban areas, have developed resistance to the commonly used insecticides, primarily DDT and deltamethrin. This finding calls for resistance management and developing counter measures to mitigate the spread of resistance.

Keywords: Aedes albopictus, Insecticide resistance, Biochemical assay, Kdr, Urbanization, Guangzhou

\footnotetext{
*Correspondence: guiyuny@uci.edu; xgchen2001@hotmail.com

${ }^{1}$ Department of Pathogen Biology, Guangdong Provincial Key Laboratory of

Tropical Disease Research, School of Public Health, Southern Medical

University, Guangzhou, China

Full list of author information is available at the end of the article
} 


\section{Background}

Aedes albopictus (Skuse) (Diptera: Culicidae), the Asian tiger mosquito, is an important vector of dengue, chikungunya, yellow fever and Zika viruses, which have emerged as global public health threats [1-5]. This mosquito originated at the edges of forests and bred in natural habitats, and it was previously considered a rural vector [6]. However, Ae. albopictus has adapted well to urban environments with larvae now breeding in artificial containers and has become the most important and sometimes sole vector in urban areas [7, 8]. Aedes albopictus is the primary dengue vector in China [4, 9, 10]. Guangdong Province experienced the highest incidence of dengue in mainland China in the past 40 years [11] accounting for $90 \%$ of dengue cases in China. Several major dengue fever outbreaks have occurred in this area since 1978, and Ae. albopictus was the sole vector. Since the 1990s, more than 30,000 dengue cases were reported in Guangzhou. Most of the dengue cases are present in urban areas of Guangzhou [12].

In the absence of specific antiviral therapy or a vaccine, control of Ae. albopictus-borne diseases by vector management is the sole method available for reducing the disease burden. Adult mosquito control depends largely on insecticides. However, resistance to insecticides is rising globally [13-18]. The extensive use or non-regulated application of pesticides can hamper the efficacy of larvicide and adulticide-based control programs, as demonstrated in the vector control of $A e$. aegypti $[19,20]$ and Culex pipiens quinquefasciatus [21]. It is reported that Ae. albopictus is resistant or incipient to the major insecticides currently or historically used for vector control across the world, i.e. DDT [16, 20, 22-25], malathion and bendiocarb [23] and pyrethroids $[26,27]$ such as permethrin $[14,22,23]$ and deltamethrin $[16,22,23]$. Previous studies indicated that $A e$. albopictus in Guangzhou was sensitive to all types of insecticides prior to 2002 [28]. Along with the rapid urbanization and recent regional economic development, insecticides were extensively and frequently used in Guangzhou city for dengue control in the past decade [29]. Recent studies have demonstrated that Ae. albopictus developed resistance against pyrethroids during the period when pyrethroids had been massively applied in Guangzhou [29-31].

Global surveys indicated that insecticide resistance in mosquitoes can be associated with target-site insensitivity, and/or metabolic-based detoxification. The main target site inactivity mechanisms involve (i) amino acid substitutions in the voltage gated sodium channel (VGSC) that cause a resistance phenotype to pyrethroids and DDT insecticides known as knockdown resistance $(k d r)$ [32]; and (ii) mutations in the acetylcholine esterase sequence that lead to insensitivity of this enzyme to organophosphates [33]. Metabolic detoxification has been found to be a key resistance mechanism in Anopheles and Culex mosquitoes [34, 35]. Detoxification enzymes typically linked to insecticide resistance mainly include three major gene families, cytochrome P450 monooxygenases (P450s), carboxylesterases (COEs), and glutathione S-transferases (GSTs). So far, compared to other mosquito species of public health importance such as Anopheles spp., Culex spp. and Ae. aegypti, very little is known about the molecular or biochemical basis of resistance in Ae. albopictus. Previous studies have examined general resistance status in limited number of mosquito populations in Guangzhou city. A systematic examination of Ae. albopictus resistance status and mechanism investigation in different ecological settings would provide important information on resistance distribution and guidance on resistance management.

In this study we explored insecticide resistance of larval and adult Ae. albopictus in different settings (urban, suburban and rural) in Guangzhou. We adopted biochemical and molecular assays to identify putative resistance mechanisms in Ae. albopictus adult for targetsite mutations and detoxifying enzymes up-regulation. We also investigated the insecticide application and sales in different settings in Guangzhou.

\section{Methods}

\section{Study sites}

The study was conducted in dengue endemic areas in Guangzhou, Guangdong Province, China (Table 1, Fig. 1). Guangzhou, about $200 \mathrm{~km}$ north of Hong Kong, is the largest city in Guangdong Province and key commercial harbor in southern China, with a population of 12 million according to the 2012 census survey [36]. It is located in the sub-tropical area with an annual average temperature of $21.6{ }^{\circ} \mathrm{C}$, and annual cumulative precipitation of about $1980 \mathrm{~mm}$. We selected six sites, two each in urban, suburban and rural areas, for our study.

\section{Mosquito strains and collection}

Six populations of Ae. albopictus larvae were collected from different ecological settings, i.e. two each in urban, suburban, and rural, from May to October 2014 (Table 1, Fig 1). Tonghe town in Baiyun district $\left(23^{\circ} 11^{\prime} 24^{\prime \prime} \mathrm{N}\right.$, $113^{\circ} 19^{\prime} 48^{\prime \prime} \mathrm{E}, 40 \mathrm{~m}$ above sea level, masl) and Shishu town in Yuexiu district $\left(23^{\circ} 07^{\prime} 48^{\prime \prime} \mathrm{N}, 113^{\circ} 15^{\prime} 0^{\prime \prime} \mathrm{E}, 32\right.$ masl) are urban areas with a population density of $>3000$ people $/ \mathrm{km}^{2}$. Land usage types are primarily residential and commercial buildings as well as public services such as schools and hospitals, filled with trees and grasses. Liangtian town in Baiyun district $\left(23^{\circ} 21^{\prime}\right.$ $36^{\prime \prime} \mathrm{N}, 113^{\circ} 22^{\prime} 12^{\prime \prime} \mathrm{E}, 38 \mathrm{masl}$ ) and Xinshuikeng town in Panyu County $\left(22^{\circ} 58^{\prime} 12^{\prime \prime} \mathrm{N}, 113^{\circ} 23^{\prime} 24^{\prime \prime} \mathrm{E}, 20\right.$ masl) are suburban areas with a population density of 
Table 1 Description of Aedes albopictus mosquito population collection sites from urban, suburban and rural settings in Guangzhou, China

\begin{tabular}{|c|c|c|c|c|c|c|c|}
\hline \multirow{2}{*}{$\begin{array}{l}\text { Geographical } \\
\text { classification }\end{array}$} & \multirow[t]{2}{*}{ District } & \multirow[t]{2}{*}{ Village } & \multirow{2}{*}{$\begin{array}{l}\text { Mosquito } \\
\text { population } \\
\text { ID }\end{array}$} & \multicolumn{2}{|l|}{ Coordinates } & \multirow{2}{*}{$\begin{array}{l}\text { Altitude } \\
\text { (m) }\end{array}$} & \multirow{2}{*}{$\begin{array}{l}\text { Human } \\
\text { density } \\
\text { (inhabitants/ } \\
\mathrm{km}^{2} \text { ) }\end{array}$} \\
\hline & & & & Latitude $\left({ }^{\circ} \mathrm{N}\right)$ & Longitude $\left({ }^{\circ} \mathrm{E}\right)$ & & \\
\hline \multirow[t]{2}{*}{ Urban } & Baiyun & Tonghe & UBT & 23.18522897 & 113.328463 & 40 & $>3000$ \\
\hline & Yuexiu & Shishu town & UYS & 23.12603999 & 113.251287 & 32 & $>3000$ \\
\hline \multirow[t]{2}{*}{ Suburban } & Baiyun & Liangtian & SBL & 23.35942101 & 113.368739 & 38 & c. 1000 \\
\hline & Panyu & Xinshuikeng & SPX & 22.96891904 & 113.390611 & 20 & c.1000 \\
\hline \multirow[t]{2}{*}{ Rural } & Conghua & Dengcun & $\mathrm{RCD}$ & 23.49894198 & 113.553073 & 27 & $<300$ \\
\hline & Panyu & Langhe & RPL & 22.82577298 & 113.342364 & 31 & $<300$ \\
\hline
\end{tabular}

approximately 1000 people $/ \mathrm{km}^{2}$, and land use includes a mixture of residential, manufacturing, and farmland. Dengcun village in Conghua County $\left(23^{\circ} 30^{\prime} 0^{\prime \prime} \mathrm{N}, 113^{\circ}\right.$ $33^{\prime} 0^{\prime \prime} \mathrm{E}, 27 \mathrm{masl}$ ) and Lanhe village in Panyu County $\left(22^{\circ} 49^{\prime} 48^{\prime \prime} \mathrm{N}, 113^{\circ} 20^{\prime} 24^{\prime \prime} \mathrm{E}, 31 \mathrm{masl}\right)$ are rural areas with a population density of $<300$ people $/ \mathrm{km}^{2}$, where land is primarily used for agriculture such as rice and vegetable farming, and forest.

\section{Insecticide resistance bioassays Larval resistance bioassays}

Four insecticides of technical grade were used. Three chemical insecticides were from the Chinese Center for Disease Control and Prevention (China CDC): propoxur (95.56\% pure), deltamethrin (94.62\% pure) and malathion (95\% pure), and one microbial larvicide: Bacillus thuringiensis israelensis (Bti) (7000 ITU/mg, Wuhan Nature's Favour Bioengineering Co., Ltd., Wuhan city,
China). All insecticides except Bti (which was diluted in water) were diluted in acetone to the required dosage following WHO guidelines [37]. All bioassays were performed using Ae. albopictus collected directly from the field after species identification. A set of 25 third- and fourth-instars larvae was incubated in $99 \mathrm{ml}$ of distilled water, to which $1 \mathrm{ml}$ of insecticide solution at the required concentration was added. Three replicates were tested for each concentration. Five to nine concentrations, providing a range of mortalities between 10 and $95 \%$, were used to determine $\mathrm{LC}_{50}$ values (the $50 \%$ mortality lethal concentration). Mosquitoes of the Foshan strain, which have been reared in the laboratory since 1981 without insecticide exposure, were used as a control. Larval mortality was recorded after $24 \mathrm{~h}$ exposure. Control bioassays were conducted by adding $1 \mathrm{ml}$ of acetone to $99 \mathrm{ml}$ of distilled water. Temperature and relative humidity were maintained at $27 \pm 2{ }^{\circ} \mathrm{C}$ and $80-$

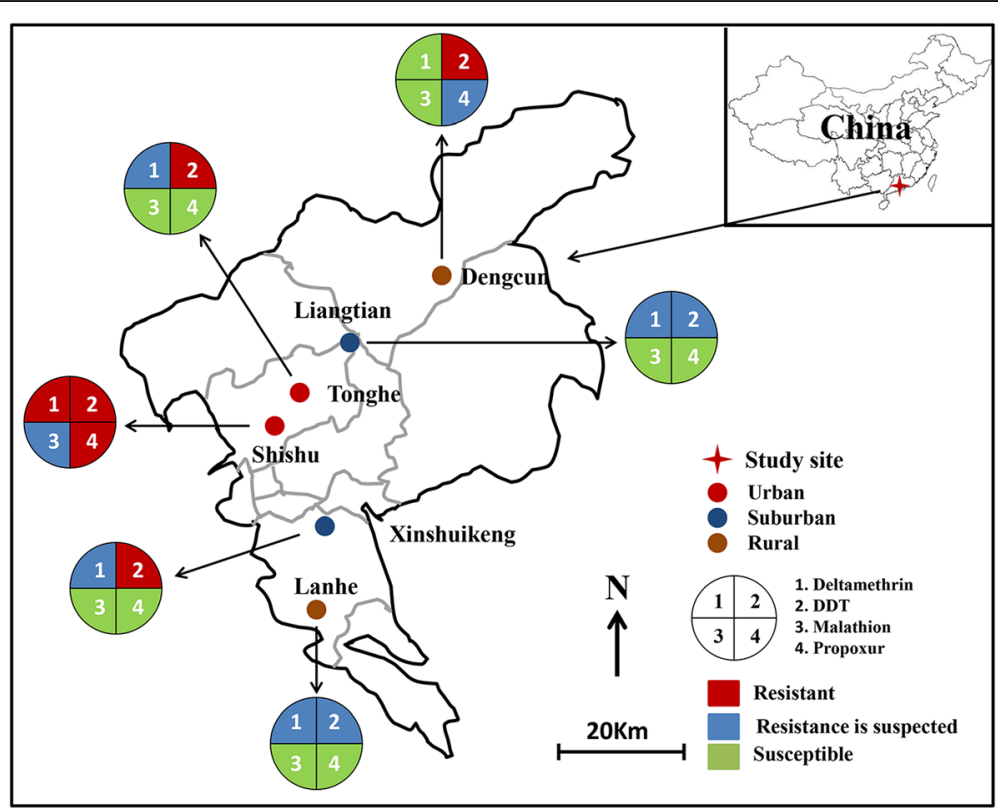

Fig. 1 Map of study areas and insecticide resistance status of adult Aedes albopictus in three ecological settings in Guangzhou, China 
90\%, respectively, in an incubator with a 16:8 h light:dark period.

\section{Adult resistance bioassays}

For each strain, five batches of 20 non-blood-fed females (3-5 day-old; $n=100)$ reared from field-collected immature Ae. albopictus were subjected to insecticide susceptibility test against $0.05 \%$ deltamethrin, malathion $(0.8 \%)$, propoxur $(0.1 \%)$ and DDT (4\%) following the standard WHO tube test protocol [38]. Briefly, we defined resistant mosquitoes as mosquitoes that survived $24 \mathrm{~h}$ after the end of the bioassay, and susceptible mosquitoes as the mosquitoes that were knocked down during the $60 \mathrm{~min}$ exposure time or that died within the $24 \mathrm{~h}$ recovery period. Mosquitoes were considered knocked down if they were unable to fly when they were mechanically stimulated. [39] Mosquitoes of the Foshan strain, which have been reared in the laboratory since 1981 without insecticide exposure, were used as a control (hereafter referred to as laboratory susceptible strain). WHO test and control papers were supplied by China $\mathrm{CDC}$, except for deltamethrin which was supplied by the School of Biological Sciences, Universiti Sains Malaysia (11800 Minden, Penang, Malaysia). The knockdown time (KDT) of females was reported every 10 min during the $60 \mathrm{~min}$ exposure period. Mortality was scored after the $24 \mathrm{~h}$ recovery period. After the bioassay, one leg of each mosquito was removed and stored individually in 95\% alcohol for subsequent DNA analysis.

\section{Metabolic enzyme activity assays}

Three metabolic enzymes, P450s, GSTs, and COEs, were analyzed on single individuals from 3 to 5 day-old F0 females without insecticide exposure, and on the laboratory susceptible strain following previously published protocols [40]. Briefly, mean absorbance values for each tested mosquito and enzyme were converted into enzyme activity and standardized based on the total protein amount. Total protein was measured for each mosquito using the method of Bradford [40]. All measurements were done in duplicate. COE activity was measured following the method of Hosokawa \& Satoh [41]. Spontaneous hydrolysis was used as a blank control. $\mathrm{COE}$ activity was calculated as $\mu \mathrm{mol}$ of p-nitrophenol formed per min per mg protein, using the formula: $\Delta \mathrm{ab}$ sorbance $/ \mathrm{min}-\Delta$ blank $/ \mathrm{min}) \times 1.0 / 16.4 \times 0.05 \times$ protein $(\mathrm{mg} / \mathrm{ml})$. An absorption coefficient of $16,400 \mathrm{M}$ was used [42]. For each mosquito population and each insecticide, 30 female adult mosquitoes were tested.

\section{DNA extraction and $k d r$ mutations detection}

Genomic DNA was extracted from individual mosquitoes using Fast Tissue-to-PCR Kit (Sigma-Aldrich, Missouri, USA) following the product protocol. Extracted
DNA was stored at $4{ }^{\circ} \mathrm{C}$ or used immediately for PCR. All survivors and 40 randomly selected (when available) dead specimens after DDT and deltamethrin bioassay exposure were genotyped at the VGSC gene to detect mutations within domains II, III and IV, by direct sequencing of PCR products that contained the specific domains following previously published protocols [43]. Sequences were aligned and analyzed with Sequencher 5.0 (Gene Codes, Ann Harbor, Michigan, USA).

\section{Insecticide usage and sales survey}

An insecticide sales and usage survey was conducted in May 2014 with a usage questionnaire from individual residents, the community, and agriculture, as well as insecticide sales from the shops. Insecticides usage included brand name, component content and frequency of application for agricultural and/or public health. At each site, residential insecticide usage surveys were administered to 80 households, 20 households for agriculture application, 8 communities for adult and larvae mosquito control, and 10 shops were administered insecticide sales surveys.

\section{Statistical analysis}

Mosquito resistance status was classified based on the 2013 WHO standard [39]: resistant if mortality is less than $90 \%$, probable resistant if mortality between 90 and $97 \%$, and susceptible if mortality $>97 \%$. Larval median lethal concentration $\left(\mathrm{LC}_{50}\right)$ and adult $50 \%$ knockdown times $\left(\mathrm{KDT}_{50}\right)$ were estimated with the log-probit model [44]. For the same insecticide, among-site difference in $\mathrm{LC}_{50}$ was tested by pair-wise comparison of the regression slopes of the Probit model. Intensity of resistance was measured using resistant ratio $\left(R_{50}\right)$ defined by ( $\mathrm{LC}_{50}$ of field population)/( $\mathrm{LC}_{50}$ of susceptible population) for insecticide concentration, or by $\left(\mathrm{KDT}_{50}\right.$ of field population $) /\left(\mathrm{KDT}_{50}\right.$ of susceptible population) for knockdown time. Generalized linear model (GLiM) was used to examine whether adult mortality in the WHO standard tube bioassay differ significantly among localities. Association between $k d r$ mutations and resistance phenotype was examined using Fisher's exact test, and odds ratio was calculated for each $k d r$ allele. Statistical comparisons of detoxification enzyme levels between the laboratory susceptible strain and the field populations were assessed with the Student's t-test. In the case that multiple comparisons were conducted, the significance level was adjusted accordingly.

\section{Results}

Larval resistance bioassays

Using the resistance ratio of 2.0 as the threshold value for declaring resistance for mosquito larvae, all mosquito populations were susceptible to $B t i$ with $R_{50}$ ranging 
from 0.39 to 1.06 , and susceptible to malathion with $\mathrm{RR}_{50}$ ranging from 0.74 to 1.94 (Table 2). All six populations were resistant against deltamethrin, with $\mathrm{LC}_{50}$ ranging 0.011 to $0.038 \mathrm{mg} / \mathrm{l}$ and $\mathrm{RR}_{50}$ ranging from 11 to 38 (Table 2). The urban population exhibited the highest $\mathrm{LC}_{50}$ in testing against deltamethrin and propoxur.

\section{Adult resistance bioassays}

Using the $90 \%$ mortality rate resistance threshold value designated by the WHO [45], two urban and one rural Ae. albopictus populations were resistant against DDT. Populations from urban areas had the lowest mortality rates against DDT (75-80\%). Only one urban population showed resistance to deltamethrin, and this population was also resistant to propoxur (Additional file 1: Table S1). All six populations were susceptible to malathion. Moreover, $\mathrm{KDT}_{50}$ of field Ae. albopictus populations were longer than those of control population when exposed to DDT, deltamethrin, and malathion, as indicated by $K_{R R}>1.0$ for field populations from all sites (Additional file 1: Table S1).

\section{Metabolic enzyme activities and association with resistance}

Comparison of the detoxification enzyme activity among the field populations and the laboratory susceptible strain without insecticide exposure found that P450 levels were significantly higher in adults from SPX and $\operatorname{SBL}\left(t_{(39)}=1.87, P=0.034 ; t_{(33)}=5.26, P<0.001\right)$ (Fig. 2 ). GST levels were significantly higher in four populations, and COE levels were significantly higher in one population $\left(t_{(39)}=2.11, P=0.021\right.$ ) (Fig. 2) compared to the laboratory susceptible strain.

\section{$k d r$ genotyping}

Sequences of domains II (480 bp), III (2347 bp) and IV (280 bp) of the VGSC gene were obtained from a total of 111 resistant or susceptible mosquitoes after deltamethrin resistance bioassay and 305 individuals after DDT resistance bioassay. All mutations in codons 989 ,

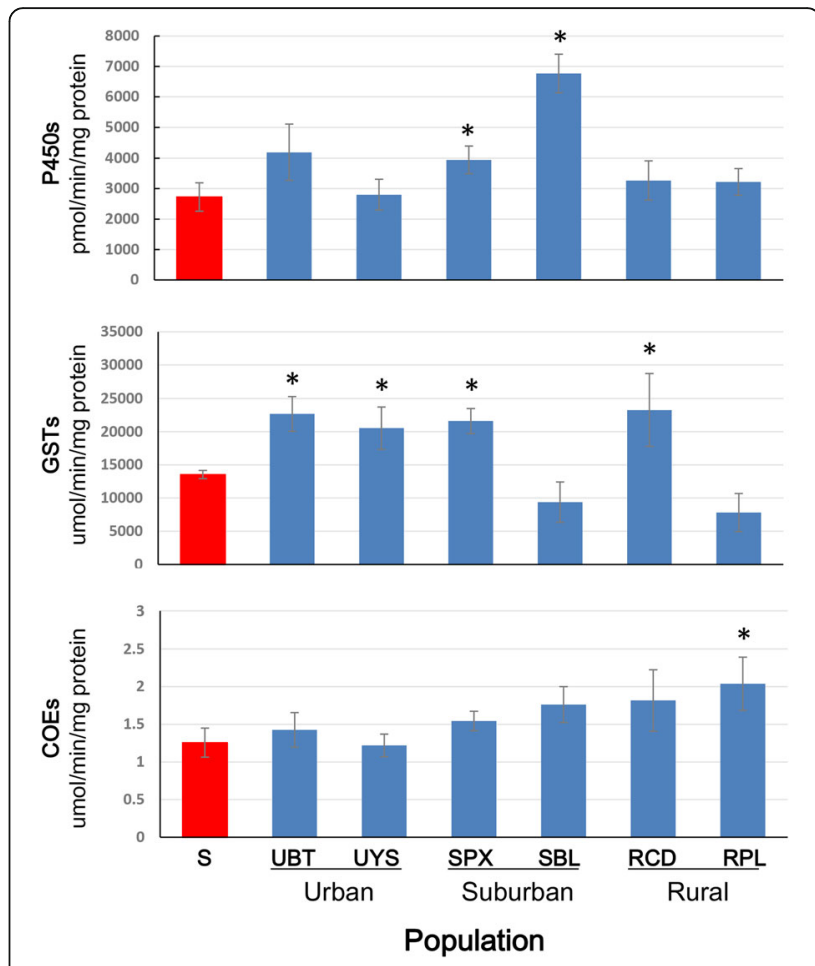

Fig. 2 Activity of detoxification enzymes in field collected Aedes albopictus adult mosquitoes from Guangzhou, China in comparison to the laboratory susceptible strain. Error bar is the standard error of the mean. An asterisk $\left(^{*}\right)$ indicates a significant difference between the population and the laboratory susceptible strain at $P<0.05$. Abbreviations: P450, monooxygenases (P450s); COEs,

carboxylesterase; GSTs, glutathione-S transferases; S, laboratory susceptible strain

1011 and 1016 within domains II or IV were synonymous (codon nomenclature based on Musca domestica $V G S C$ gene according to the accepted $k d r$ codon nomenclature method). Genotyping of mosquitoes after deltamethrin bioassay was done in UBT and UYS populations due to the very small number of resistant individuals in the other four populations. At codon 1534,

Table 2 Resistance bioassay results of larval Aedes albopictus in urban, suburban and rural settings in Guangzhou, China. Sites in the same column connected by different letters represent a significant difference in resistance levels at $P<0.05$

\begin{tabular}{|c|c|c|c|c|c|c|c|c|c|}
\hline \multirow[t]{2}{*}{ Location } & \multirow{2}{*}{$\begin{array}{l}\text { Population } \\
\text { name }\end{array}$} & \multicolumn{2}{|l|}{ Bti } & \multicolumn{2}{|l|}{ Deltamethrin } & \multicolumn{2}{|l|}{ Propoxur } & \multicolumn{2}{|l|}{ Malathion } \\
\hline & & $\mathrm{LC}_{50}(95 \% \mathrm{Cl})(\mathrm{mg} / \mathrm{l})$ & $\mathrm{RR}_{50}$ & $\mathrm{LC}_{50}(95 \% \mathrm{Cl})(\mathrm{mg} / \mathrm{l})$ & $\mathrm{RR}_{50}$ & $\mathrm{LC}_{50}(95 \% \mathrm{Cl})(\mathrm{mg} / \mathrm{l})$ & $\mathrm{RR}_{50}$ & $\mathrm{LC}_{50}(95 \% \mathrm{Cl})(\mathrm{mg} / \mathrm{l})$ & $\mathrm{RR}_{50}$ \\
\hline \multirow[t]{2}{*}{ Urban } & UBT & $0.016(0.009-0.026)$ & 0.4 & $0.016(0.010-0.026)^{b c}$ & $16.0^{*}$ & $2.29(1.58-3.06)^{\mathrm{ab}}$ & $2.6^{*}$ & $0.177(0.159-0.198)$ & 1.3 \\
\hline & UYS & $0.035(0.030-0.040)$ & 1.0 & $0.038(0.032-0.046)^{a}$ & $38.0^{*}$ & $3.29(2.47-4.39)^{a}$ & $3.7^{*}$ & $0.260(0.227-0.301)$ & 1.9 \\
\hline \multirow[t]{2}{*}{ Suburban } & SBL & $0.038(0.024-0.058)$ & 1.1 & $0.017(0.014-0.022)^{b}$ & $17.0^{*}$ & $1.52(1.09-2.08)^{c}$ & 1.7 & $0.109(0.096-0.125)$ & 0.8 \\
\hline & SPX & $0.016(0.012-0.021)$ & 0.4 & $0.011(0.009-0.013)^{c}$ & $11.0^{*}$ & $2.14(1.89-2.40)^{b}$ & $2.4^{*}$ & $0.099(0.088-0.113)$ & 0.7 \\
\hline \multirow[t]{2}{*}{ Rural } & RDS & $0.014(0.007-0.002)$ & 0.4 & $0.014(0.007-0.024)^{b c}$ & $14.0^{*}$ & $1.41(1.25-1.59)^{c}$ & 1.6 & $0.145(0.106-0.204)$ & 1.1 \\
\hline & $\mathrm{RPL}$ & $0.014(0.009-0.021)$ & 0.4 & $0.022(0.020-0.026)^{b}$ & $22.0^{*}$ & $2.87(2.53-3.19)^{\mathrm{a}}$ & $3.3^{*}$ & $0.217(0.171-0.282)$ & 1.6 \\
\hline Lab strain & LSS & $0.036(0.028-0.047)$ & 1 & $0.001(0.001-0.001)$ & 1 & $0.879(0.802-0.952)$ & 1 & $0.134(0.121-0.149)$ & 1 \\
\hline
\end{tabular}

Abbreviations: $L C_{50}$ lethal concentration that kills $50 \%$ of the population (mg/l), $R R_{50}$ resistant ratio, $L C_{50}$ field population/LC 50 susceptible strain, $B t i \quad 7000$ ITU/mg *Significant resistance compared to the laboratory susceptible strain as indicated by at least a 2 -fold higher RR $\mathrm{R}_{50}$ value relative to the laboratory susceptible strain 
polymorphisms were detected in both populations with two mutated codons, F1534S and F1534 L. Both $k d r$ mutations F1534S and F1534 L conferred protection against deltamethrin, with odds ratios of 33.6 and 9.3 for F1534S $(P<0.001)$, and odds ratios of 15.7 and 19.8 for F1534 L $(P<0.05)$ in the UBT and UYS populations, respectively (Table 3 ). In populations that underwent DDT resistant bioassay, mutated codons at the VGSC gene was detected in all populations except one rural population (RPL). However, $k d r$ mutations were not significantly associated with mosquito resistance to DDT after a significance level adjustment for multiple comparisons (Table 4). No $k d r$ mutation was detected in the laboratory susceptible populations.

\section{Insecticide use and sales survey}

Field surveys revealed that biological insecticides, pyrethroids, organophosphates and carbamates (except organochlorine) were used for agricultural and public health pest control in the study areas (Table 5). Overall, diverse types of insecticides are being used in the study sites. The pyrethroids-based insecticides were more commonly used than organophosphates. Pyrethrins (mainly cypermethrin and beta-cypermethrin) were the insecticides most frequently used in Guangzhou for community level adult Ae. albopictus control. However, the frequency of pyrethrin applications was higher in suburban and rural areas (5-7 times/week) than in urban areas (0-1 time/week). Pyrethrin and organophosphorus were the main insecticides used in suburban areas for agricultural purposes with a frequency of 1-2 times/week. In rural areas, organophosphorus and carbamates were the main insecticides used in agriculture with a frequency of 12 times/month.

Organophosphorus (mainly temephos, mevinphos and fenthion) and biological insecticides (mainly Bti) were used for Ae. albopictus larval control but only in urban areas with a frequency of 1-2 times/month. No insecticide/larvicide was used for larval control in suburban or rural areas (Table 5).

\section{Discussion}

Guangzhou is a dengue epidemic area and has been experiencing frequent outbreaks of dengue fever in China over the past 40 years. Also, it is prone to Zika virus outbreaks due to the presence of recently imported Zika cases in the area [46]. Thus, it is necessary to address the insecticide resistance problem of Ae. albopictus since insecticides were popularly used for mosquito control in the past 40 years. The present study is by far the most comprehensive research into insecticide resistance in Ae. albopictus mosquitoes from different ecological settings in Guangzhou. Two non-synonymous mutations at position 1534 of $k d r$ gene domain III were identified with significant associations to deltamethrin resistance. Additionally, biochemical assays indicated that the three classes of detoxification enzymes may play a role in insecticide resistance in adult mosquitoes. Furthermore, insecticide usage surveys indicated a diverse use of insecticides in the study areas.

Our study area (Guangzhou) is in the subtropical region with a suitable climate for Ae. albopictus development and reproduction. Since the infamous and most deadly 2014 dengue epidemic in Guangdong Province, the city of Guangzhou has intensified vector control programs primarily through more frequent insecticide sprays [47]. In the present study, we illustrated that insecticide usage varied in different ecological settings (urban, suburban, and rural). Insecticide spray in urban areas was more frequent and intense than in suburban and rural areas. Adult Ae. albopictus populations from urban areas were more resistant to deltamethrin, DDT and propoxur than populations from rural areas, while no resistance to malathion was detected in the populations examined. Larval Ae. albopictus populations from urban areas were also more resistant to deltamethrin than populations from suburban and rural areas, whereas, all populations were susceptible to Bti and malathion.

According to the insecticide use survey, we observed frequent deltamethrin insecticide applications in the community, which coincided with elevated deltamethrin resistance. Usage of pyrethroids in urban areas was more

Table 3 Association between mutations at codon 1534 of the voltage-gated sodium channel gene and phenotypic resistance to deltamethrin in two Aedes albopictus populations from Guangzhou, China

\begin{tabular}{|c|c|c|c|c|c|c|c|c|c|c|c|c|c|}
\hline \multirow[t]{2}{*}{ Area } & \multirow[t]{2}{*}{ Population } & \multirow[t]{2}{*}{ Phenotype } & \multirow[t]{2}{*}{$n$} & \multicolumn{6}{|c|}{ Genotype } & \multicolumn{2}{|l|}{ Odds ratio $(95 \% \mathrm{Cl})$} & \multicolumn{2}{|c|}{$P$-value of Fisher's exact probability tes } \\
\hline & & & & $\overline{F F}$ & FS & SS & $\mathrm{FL}$ & $\mathrm{LL}$ & $\overline{S L}$ & F1534S & F1534 L & F1534S & F1534 L \\
\hline \multirow[t]{4}{*}{ Urban } & UBT & $\mathrm{R}$ & 12 & 0 & 0 & 9 & 1 & 0 & 2 & $33.6(4.26-263.97)$ & $15.7(1.46-168.08)$ & $<0.0001^{*}$ & $0.023^{*}$ \\
\hline & & S & 42 & 16 & 12 & 6 & 3 & 1 & 4 & & & & \\
\hline & UYS & $\mathrm{R}$ & 20 & 0 & 1 & 2 & 1 & 6 & 10 & $9.3(1.94-44.55)$ & $19.8(4.17-93.99)$ & $0.001^{*}$ & $<0.0001^{*}$ \\
\hline & & $S$ & 37 & 8 & 9 & 5 & 6 & 3 & 6 & & & & \\
\hline
\end{tabular}

Abbreviations: $R$ resistant, $S$ susceptible, $F F$ homozygous phenylalanine/phenylalanine, $F S$ heterozygotes phenylalanine/ leucine, SS homozygous serine/serine, $F L$ heterozygotes phenylalanine/ leucine, $L L$ homozygous leucine/ leucine, $S L$ heterozygotes serine/leucine ${ }^{*} P<0.05$ 
Table 4 Genotyping results of the voltage-gated sodium channel gene at 1534 codon and association with resistance to DDT in five Aedes albopictus populations in Guangzhou, China. The significance threshold is $P<0.01$ after Bonferroni correction for multiple testing

\begin{tabular}{|c|c|c|c|c|c|c|c|c|c|c|c|c|c|}
\hline \multirow[t]{2}{*}{ Area } & \multirow[t]{2}{*}{ Population } & \multirow[t]{2}{*}{ Phenotype } & \multirow[t]{2}{*}{$n$} & \multicolumn{6}{|c|}{ Genotype } & \multicolumn{2}{|c|}{ Odds ratio $(95 \% \mathrm{Cl})$} & \multicolumn{2}{|c|}{$P$-value of Fisher's exact probability test } \\
\hline & & & & $\mathrm{FF}$ & FS & SS & $\mathrm{FL}$ & $\mathrm{LL}$ & LS & F1534S & F1534 L & F1534S & F1534 L \\
\hline \multirow[t]{4}{*}{ Urban } & UBT & $\mathrm{R}$ & 28 & 2 & 11 & 12 & 1 & 0 & 2 & $1.9(0.94-3.96)$ & $1.9(0.38-9.34)$ & 0.052 & 0.353 \\
\hline & & S & 46 & 15 & 9 & 18 & 1 & 0 & 3 & & & & \\
\hline & UYS & $\mathrm{R}$ & 39 & 5 & 9 & 7 & 6 & 1 & 11 & $2.3(1.19-4.59)$ & $2.2(1.00-4.86)$ & 0.010 & 0.040 \\
\hline & & S & 52 & 13 & 19 & 3 & 10 & 1 & 7 & & & & \\
\hline \multirow[t]{4}{*}{ Suburban } & SBL & $\mathrm{R}$ & 10 & 3 & 6 & 1 & 0 & 0 & 0 & $0.9(0.31-2.51)$ & na & 0.519 & 0.542 \\
\hline & & S & 29 & 11 & 9 & 7 & 1 & 0 & 1 & & & & \\
\hline & SPX & $\mathrm{R}$ & 10 & 0 & 1 & 8 & 0 & 0 & 1 & $4.2(0.50-34.24)$ & $2.0(0.11-37.83)$ & 0.143 & 0.589 \\
\hline & & S & 35 & 5 & 2 & 22 & 0 & 0 & 6 & & & & \\
\hline \multirow[t]{2}{*}{ Rural } & $\mathrm{RCD}$ & $\mathrm{R}$ & 13 & 8 & 3 & 2 & 0 & 0 & 0 & $1.0(0.37-2.72)$ & na & 0.587 & 0.346 \\
\hline & & S & 43 & 22 & 16 & 1 & 0 & 0 & 4 & & & & \\
\hline
\end{tabular}

Abbreviations: $F$ wildtype F1534 allele, S F1534S allele, L F1534 L, $R$ resistant, S susceptible, na not applicable, FF homozygous phenylalanine/phenylalanine, FS heterozygotes phenylalanine/ leucine, SS homozygous serine/serine, FL heterozygotes phenylalanine/ leucine, $L L$ homozygous leucine/ leucine, $S L$ heterozygotes serine/leucine

frequent than in suburban and rural areas. DDT was used extensively in the 1960s in China for agricultural pest control, but was banned in the 1980s [15, 18]. Since the 1980s, especially in recent years, pyrethroids were massively used to control Ae. albopictus in China [29, 48]. The large scale mosquito control program within urban areas likely contributed to the increasing selection pressure on insecticide resistant Ae. albopictus. Wide usage of insecticide treated nets (ITNs) and long-lasting insecticidal nets (LLINs) in African countries has been linked to the rapid development of pyrethroids resistance in malaria vector mosquitoes over the past decade $[49,50]$. The present study suggests that pyrethroid resistance is emerging in Ae. albopictus in our study area,

Table 5 Survey of insecticide types and usage in three study settings in Guangzhou, China

\begin{tabular}{|c|c|c|c|c|c|c|c|c|}
\hline & \multirow{2}{*}{$\begin{array}{l}\text { Mosquito } \\
\text { status }\end{array}$} & \multirow[t]{2}{*}{$n$} & \multicolumn{2}{|l|}{ Urban } & \multicolumn{2}{|l|}{ Suburban } & \multicolumn{2}{|l|}{ Rural } \\
\hline & & & Insecticide & Frequency & Insecticide & Frequency & Insecticide & Frequency \\
\hline \multirow[t]{2}{*}{$\begin{array}{l}\text { Community } \\
\text { usage }\end{array}$} & Adult & 8 & $\begin{array}{l}\text { Pyrethrins: cypermethrin, } \\
\text { beta-cypermethrin }\end{array}$ & $\begin{array}{l}1-2 \\
\text { times/ } \\
\text { month }\end{array}$ & $\begin{array}{l}\text { Pyrethrin: cypermethrin; } \\
\text { Organophosphates: DDVP }\end{array}$ & $\begin{array}{l}\text { None or } 1 \\
\text { time/year }\end{array}$ & $\begin{array}{l}\text { Pyrethrin: } \\
\text { cypermethrin }\end{array}$ & $\begin{array}{l}\text { None or } 1 \\
\text { time/year }\end{array}$ \\
\hline & Larvae & 8 & $\begin{array}{l}\text { Organophosphates: } \\
\text { temephos, mevinphos, } \\
\text { fenthion; Biological } \\
\text { insecticides: bacillus } \\
\text { sphaericus }\end{array}$ & $\begin{array}{l}1-2 \\
\text { times/ } \\
\text { month }\end{array}$ & - & - & - & - \\
\hline Shop sold & Adult & 10 & $\begin{array}{l}\text { Organophosphates: } \\
\text { chlorpyrifos; carbamates: } \\
\text { propoxur; Pyrethrin: } \\
\text { prallethrin, cypermethrin, } \\
\text { beta-cypermethrin, } \\
\text { meperfluthrin, dimeflu } \\
\text { thrin, Es-Bioallethrin, } \\
\text { tetramethrin }\end{array}$ & - & $\begin{array}{l}\text { Pyrethrin: cypermethrin, } \\
\text { beta-cypermethrin, per } \\
\text { methrin, meperfluthrin, } \\
\text { dimefluthrin, prallethrin; } \\
\text { Carbamates: propoxur Or } \\
\text { ganophosphates: } \\
\text { chlorpyrifos }\end{array}$ & - & $\begin{array}{l}\text { Organophosphates: } \\
\text { DDVP, phoxim; } \\
\text { Pyrethrin: meperfluthrin, } \\
\text { dimefluthrin, Es- } \\
\text { Bioallethrin, tetrame } \\
\text { thrin, cypermethrin, } \\
\text { deyphenothrin }\end{array}$ & - \\
\hline $\begin{array}{l}\text { Resident } \\
\text { usage }\end{array}$ & Adult & 80 & $\begin{array}{l}\text { Pyrethrin: meperfluthrin, } \\
\text { dimefluthrin, prallethrin, } \\
\text { rich-d-transallethrin }\end{array}$ & $\begin{array}{l}\text { None or } 1 \\
\text { time/ } \\
\text { week(use } \\
\text { at night) }\end{array}$ & $\begin{array}{l}\text { Pyrethrin: meperfluthrin, } \\
\text { dimefluthrin, prallethrin, } \\
\text { rich-d-transallethrin, Es- } \\
\text { Bioallethrin }\end{array}$ & $\begin{array}{l}5-7 \\
\text { times/ } \\
\text { week(use } \\
\text { at night) }\end{array}$ & $\begin{array}{l}\text { Pyrethrin: dimefluthrin, } \\
\text { Es-Bioallethrin, rich-d- } \\
\text { transallethrin, meperflu } \\
\text { thrin, tetramethrin }\end{array}$ & $\begin{array}{l}5-7 \\
\text { times/ } \\
\text { week (use } \\
\text { at night) }\end{array}$ \\
\hline \multirow[t]{2}{*}{$\begin{array}{l}\text { Agriculture } \\
\text { usage }\end{array}$} & Rice field & 10 & - & - & - & - & $\begin{array}{l}\text { Organophosphates: } \\
\text { acephate }\end{array}$ & $\begin{array}{l}1-2 \text { times/ } \\
\text { month }\end{array}$ \\
\hline & $\begin{array}{l}\text { Farm } \\
\text { land }\end{array}$ & 10 & - & - & $\begin{array}{l}\text { Pyrethrin: beta- } \\
\text { cypermethrin, meperflu } \\
\text { thrin; Organophosphates: } \\
\text { DDVP, phoxim, Chlorpyrifos, } \\
\text { dipterex }\end{array}$ & $\begin{array}{l}1-2 \\
\text { times/ } \\
\text { week }\end{array}$ & $\begin{array}{l}\text { Organophosphates: } \\
\text { DDVP, dipterex, } \\
\text { acephate; Carbamates: } \\
\text { methyl isocyanate }\end{array}$ & $\begin{array}{l}1 \text { time/ } \\
\text { month }\end{array}$ \\
\hline
\end{tabular}


and it is important to develop an appropriate insecticide resistance management plan. Meanwhile, there is an urgency to adopt alternative effective vector control methods that are not reliant on chemical insecticide such as odorbaited traps, larval resource reduction [20] and biological control [7], as well as new chemical insecticides [30].

Among all the populations from Guangzhou tested for $k d r$ mutations, two mutations (F1534S and F1534 L) were detected, and these mutations were positively associated with pyrethroid resistance. This result is consistent with previous studies which found that F1534S mutation was correlated with the deltamethrin resistance [51-53]. Thus, monitoring the $k d r$ mutation frequency may aid the surveillance of pyrethroid resistance in Ae. albopictus. In addition, we found significantly higher P450, GST and $\mathrm{COE}$ enzyme activities in the field mosquitoes. Literature has reported potential role of GST in DDT resistance $[24,54,55]$ and $\mathrm{P} 450$ s in pyrethroid resistance in mosquitoes, but the precise role of these detoxification enzymes in Ae. albopictus insecticide resistance needs further study.

An interesting finding from this study is the revealed patchy distribution of insecticide resistant $A e$. albopictus. Within the urban and rural areas, mosquito populations differed considerably in resistance. One implication of this finding is that we need to monitor the insecticide resistance status in local mosquito populations, and develop efficient mosquito control strategies that take the patchy distribution of resistance into consideration. Currently, biological insecticides such as Bti are not frequently applied for mosquito control in China and no resistance has been detected, thus they can be considered as alternative insecticides for vector control.

\section{Conclusions}

Our findings urgently call for timely surveillance of insecticide resistance as well as attention to the roles of metabolic detoxification enzymes and $k d r$ mutations in insecticide resistant Ae. albopictus. The threat of dengue outbreak calls for an intensified and effective vector control program. Appropriate insecticide resistance management and additional vector control tools that are not reliant on synthetic insecticides are urgently needed to reduce dengue transmission.

\section{Additional file}

Additional file 1: Table S1. Knockdown time (KDT) and mortality rate of Aedes albopictus populations from urban, suburban and rural settings in Guangzhou, China using the standard WHO tube susceptibility bioassay against four insecticides. (XLSX $12 \mathrm{~kb}$ )

\section{Abbreviations}

Bti: Bacillus thuringiensis israelensis; COEs: Carboxylesterase; DDT: Dichlorodiphenyl-trichloroethane; GSTs: Glutathione S-transferase; kdr: Knockdown resistance; P450s: P450 monooxygenase

\section{Acknowledgments}

We thank Lijie Yao, Xueli Cai, Tong Liu, Zhuanzhuan Liu, Guiquan Lai, Qiankun Chen, Hehai Huang and Yuhang Huang for their assistance with the larval collection and insecticide usage survey.

\section{Funding}

This study was supported by the grants from the National Key R\&D Program of China (2016YFC1200500, 2017YFC1201000), the National Nature Science Foundation of China (81371845, 81420108024, 81528013), the Natural Science Foundation of Guangdong Province (2014A030312016,

2016A020251001), the Guangzhou Synergy Innovation Key Program for Health $(201508020263,201605030010)$ and the National Institutes of Health, USA (R01 Al083202 and D43 TW009527).

\section{Availability of data and materials}

All the important information regarding the article is available in the main text.

\section{Authors' contributions}

$Y L, G Y$ and $X C$, conceived the study and coordinated its implementation. $Y L$, $D Z, X C$ and GY participated in the experimental design. YL, JX, HZ, WQ, XS, YW, KW, and SC performed the experiments and drafted the manuscript which was critically revised by JX, GZ and XC. All authors read and approved the final manuscript.

\section{Ethics approval and consent to participate}

No specific permits were required for mosquito field specimens' collection, which were performed in urban, suburban and rural areas of Guangzhou,

China. This study did not involve endangered or protected species.

\section{Consent for publication}

Not applicable

\section{Competing interests}

The authors declare that they have no competing interests.

\section{Publisher's Note}

Springer Nature remains neutral with regard to jurisdictional claims in published maps and institutional affiliations.

\section{Author details}

${ }^{1}$ Department of Pathogen Biology, Guangdong Provincial Key Laboratory of Tropical Disease Research, School of Public Health, Southern Medical University, Guangzhou, China. ${ }^{2}$ Key Laboratory of Translation Medicine Tropical Diseases of Ministry of Education, Hainan Medical University, Haikou, Hainan, China. ${ }^{3}$ Department of Pathogen Biology, Hainan Medical University, Haikou, Hainan, China. ${ }^{4}$ Program in Public Health, School of Medicine, University of California, Irvine, USA. ${ }^{5}$ Department of Vector Control, Centers for Disease Control and Prevention of Guangdong Province, Guangzhou, China.

Received: 11 April 2017 Accepted: 10 December 2017 Published online: 03 January 2018

\section{References}

1. Schuffenecker I, Iteman I, Michault A, Murri S, Frangeul L, Vaney MC, et al. Genome microevolution of chikungunya viruses causing the Indian Ocean outbreak. PLoS Med. 2006;3(7):e263.

2. Sergon K, Njuguna C, Kalani R, Ofula V, Onyango C, Konongoi LS, et al. Seroprevalence of chikungunya virus (CHIKV) infection on Lamu Island, Kenya, October 2004. Am J Trop Med Hyg. 2008;78(2):333-7.

3. Rezza G. Aedes albopictus and the reemergence of dengue. BMC Public Health. 2012;12:72

4. Peng HJ, Lai HB, Zhang QL, Xu BY, Zhang H, Liu WH, et al. A local outbreak of dengue caused by an imported case in Dongguan China. BMC Public Health. 2012;12:83. 
5. Jupille H, Seixas G, Mousson L, Sousa CA, Failloux AB. Zika virus, a new threat for Europe? PLoS Negl Trop Dis. 2016;10(8):e0004901.

6. Higa Y. Dengue vectors and their spatial distribution. Trop Med Health. 2011;39(Suppl. 4):17-27.

7. Caputo B, lenco A, Cianci D, Pombi M, Petrarca V, Baseggio A, et al. The "auto-dissemination" approach: a novel concept to fight Aedes albopictus in urban areas. PLoS Negl Trop Dis. 2012;6(8):e1793.

8. Delatte H, Toty C, Boyer S, Bouetard A, Bastien F, Fontenille D. Evidence of habitat structuring Aedes albopictus populations in Reunion Island. PLoS Negl Trop Dis. 2013;7(3):e2111.

9. Li Y, Kamara F, Zhou G, Puthiyakunnon S, Li C, Liu Y, et al. Urbanization increases Aedes albopictus larval habitats and accelerates mosquito development and survivorship. PLoS Negl Trop Dis. 2014;8(11):e3301.

10. Yan JY, Zhang YJ, Mao HY, Lin JF, Chen JH, Ling F, et al. Diagnosis of a dengue fever outbreak in Yiwu city, Zhejiang province in 2009 and its molecular tracing of the pathogen. Chin J Prev Med. 2010;44(12):10916. (In Chinese)

11. Sang S, Yin W, Bi P, Zhang H, Wang C, Liu X, et al. Predicting local dengue transmission in Guangzhou, China, through the influence of imported cases, mosquito density and climate variability. PLoS One. 2014;9(7):e102755.

12. Lei L. The study of natural epidemic focus and transmission evolution model of dengue fever in Guangzhou. PhD thesis, Southern Medical University, China; 2012

13. Mouchet J. Survey of potential vectors of yellow fever in Tanzania. Bull World Health Organ. 1972;46(5):675-84

14. Chuaycharoensuk T, Juntarajumnong W, Boonyuan W, Bangs MJ, Akratanakul P, Thammapalo $S$, et al. Frequency of pyrethroid resistance in Aedes aegypti and Aedes albopictus (Diptera: Culicidae) in Thailand. J Vector Ecol. 2011;36(1):204-12.

15. Cui F, Raymond M, Qiao CL. Insecticide resistance in vector mosquitoes in China. Pest Manag Sci. 2006;62(11):1013-22.

16. Kamgang B, Marcombe S, Chandre F, Nchoutpouen E, Nwane P, Etang J, et al. Insecticide susceptibility of Aedes aegypti and Aedes albopictus in Central Africa. Parasit Vectors. 2011:4:79.

17. Ponlawat A, Scott JG, Harrington LC. Insecticide susceptibility of Aedes aegypti and Aedes albopictus across Thailand. J Med Entomol. 2005; 42(5):821-5

18. Wesson DM. Susceptibility to organophosphate insecticides in larval Aedes albopictus. J Am Mosq Control Assoc. 1990;6(2):258-64.

19. Marcombe S, Carron A, Darriet F, Etienne M, Agnew P, Tolosa M, et al Reduced efficacy of pyrethroid space sprays for dengue control in an area of Martinique with pyrethroid resistance. Am J Trop Med Hyg. 2009;80(5):745-51.

20. Karunaratne SH, Weeraratne TC, Perera MD, Surendran SN. Insecticide resistance and, efficacy of space spraying and larviciding in the control of dengue vectors Aedes aegypti and Aedes albopictus in Sri Lanka. Pestic Biochem Phys. 2013;107(1):98-105.

21. Yebakima A, Marquine M, Rosine J, Yp-Tcha MM, Pasteur N. Evolution of resistance under insecticide selection pressure in Culex pipiens quinquefasciatus (Diptera, Culicidae) from Martinique. J Med Entomol. 2004;41(4):718-25.

22. Kushwah RB, Mallick PK, Ravikumar H, Dev V, Kapoor N, Adak TP, et al. Status of DDT and pyrethroid resistance in Indian Aedes albopictus and absence of knockdown resistance (kdr) mutation. J Vector Dis. 2015;52(1):95-8.

23. Ishak $1 \mathrm{H}$, Jaal Z, Ranson $\mathrm{H}$, Wondji CS. Contrasting patterns of insecticide resistance and knockdown resistance ( $k d r)$ in the dengue vectors Aedes aegypti and Aedes albopictus from Malaysia. Parasit Vectors. 2015;8(1):181.

24. Marcombe S, Farajollahi A, Healy SP, Clark GG, Fonseca DM. Insecticide resistance status of United States populations of Aedes albopictus and mechanisms involved. PLoS One. 2014;9(7):e101992.

25. Dharshini S, Vinobaba M, Jude PJ, Karunaratne SH, Surendran SN. Prevalence and insecticide susceptibility of dengue vectors in the district of Batticaloa in eastern Sri Lanka. Tropical Med Int Health. 2011;39(2):47-52.

26. Lee RM, Choong CT, Goh BP, Ng LC, Lam-Phua SG. Bioassay and biochemical studies of the status of pirimiphos-methyl and cypermethrin resistance in Aedes (Stegomyia) aegypti and Aedes (Stegomyia) albopictus (Diptera: Culicidae) in Singapore. Trop Biomed. 2014;31(4):670-9.

27. Kawada H, Maekawa Y, Abe M, Ohashi K, Ohba SY, Takagi M. Spatial distribution and pyrethroid susceptibility of mosquito larvae collected from catch basins in parks in Nagasaki city, Nagasaki, Japan. Jpn J Infect Dis. 2010;63(1):19-24.
28. Cai SW, Lin LF, Duan JH, Yin WX. Resistance of Aedes albopictus to insecticides and its resistance management in guangdong province. Chin J Vector Biol Control. 2006;04:274-6. (In Chinese)

29. Li C, Yan Z, Jian G, Wu H, Hu Z. Resistance of Aedes albopictus to commonly used insecticides in urban area of Guangzhou. Chin J Hygienic Insecticides Equipments. 2013:06:487-9. (In Chinese)

30. Gao JR, Liu JH, Liu JH, Liu SZ. Research and control strategies for Aedes albopictus in Guangzhou, China, during recent five years. Chin J Vector Biol Control. 2014;05:483-5. (In Chinese)

31. Yiguan $W$, Xin L, Chengling L, Su T, Jianchao J, Yuhong G, et al. A survey of insecticide resistance in Aedes albopictus (Diptera: Culicidae) during a 2014 dengue fever outbreak in Guangzhou, China. J Econ Entomol. 2017:110(1):239-44.

32. Brengues C, Hawkes NJ, Chandre F, McCarroll L, Duchon S, Guillet P, et al. Pyrethroid and DDT cross-resistance in Aedes aegypti is correlated with novel mutations in the voltage-gated sodium channel gene. Med Vet Entomol. 2003:17(1):87-94.

33. Muthusamy R, Shivakumar MS. Susceptibility status of Aedes aegypti (L.) (Diptera: Culicidae) to temephos from three districts of Tamil Nadu, India. J Vector Dis. 2015;52(2):159-65.

34. Zhong D, Chang X, Zhou G, He Z, Fu F, Yan Z, et al. Relationship between knockdown resistance, metabolic detoxification and organismal resistance to pyrethroids in Anopheles sinensis. PLoS One. 2013:8(2):e55475

35. Hemingway J, Field L, Vontas J. An overview of insecticide resistance. Science. 2002;298(5591):96-7.

36. Guangdong statistical yearbook. http://www.gdstats.gov.cn/tjnj/2013/ directory/04-05.html. Accessed 2013.

37. WHO. Guidelines for laboratory and field testing of mosquito larvicides. Geneva: World Health Organization; 2005.

38. WHO. Test procedures for insecticide resistance monitoring in malaria vector mosquitoes. Geneva: World Health Organization; 2013.

39. Chang X, Zhong D, Fang Q, Hartsel J, Zhou G, Shi L, et al. Multiple resistances and complex mechanisms of Anopheles sinensis mosquito: a major obstacle to mosquito-borne diseases control and elimination in China. PLoS Negl Trop Dis. 2014;8(5):e2889.

40. Bradford MM. A rapid and sensitive method for the quantitation of microgram quantities of protein utilizing the principle of protein-dye binding. Anal Biochem. 1976;72:248-54.

41. Hosokawa M, Satoh T. Measurement of carboxylesterase (CES) activities. Curr Protoc Toxicol. 2002;Suppl 10:4.7.14

42. Ehnholm C, Kuusi T. Preparation, characterization, and measurement of hepatic lipase. Method Enzymol. 1986;129:716-38.

43. Kasai S, Ng LC, Lam-Phua SG, Tang CS, Itokawa K, Komagata O, et al. First detection of a putative knockdown resistance gene in major mosquito vector, Aedes albopictus. Jpn J Infect Dis. 2011;64(3):217-21.

44. Finney D. Probit Analysis. Cambridge: Cambridge University Press; 1971.

45. WHO. Monitoring and managing insecticide resistance in Aedes mosquito populations. Geneva: World Health Organization; 2016.

46. Liu Z, Zhou T, Lai Z, Zhang Z, Jia Z, Zhou G, et al. Competence of Aedes aegypti, Ae. albopictus, and Culex quinquefasciatus mosquitoes as Zika virus vectors, China. Emerg Infect Dis. 2017;23(7):1085-91.

47. Huang L, Luo X, Shao J, Yan H, Qiu Y, Ke P, et al. Epidemiology and characteristics of the dengue outbreak in Guangdong, southern China, in 2014. Eur J Clin Microbiol. 2016:35(2):269-77.

48. Guo FY, Wu HY, Li CY. Research progress of pyrethroid resistance of mosquito in China. Acta Parasitologica et Medica Entomologica Sinica. 2002; 9(01):50-8. (In Chinese)

49. Ranson H, N'Guessan R, Lines J, Moiroux N, Nkuni Z, Corbel V. Pyrethroid resistance in African anopheline mosquitoes: what are the implications for malaria control? Trends Parasitol. 2011;27(2):91-8.

50. Strode C, Donegan S, Garner P, Enayati AA, Hemingway J. The impact of pyrethroid resistance on the efficacy of insecticide-treated bed nets against African anopheline mosquitoes: systematic review and meta-analysis. PLoS Med. 2014;11(3):e1001619.

51. Abbott WS. A method of computing the effectiveness of an insecticide. J Econ Entomol. 1925;18:265-7.

52. Xu J, Bonizzoni M, Zhong D, Zhou G, Cai S, Li Y, et al. Multi-country survey revealed prevalent and novel f1534s mutation in voltage-gated sodium channel (VGSC) gene in Aedes albopictus. PLoS Negl Trop Dis. 2016:10(5): e0004696. 
53. Chen H, Li K, Wang $X$, Yang $X$, Lin Y, Cai F, et al. First identification of kdr allele F1534S in VGSC gene and its association with resistance to pyrethroid insecticides in Aedes albopictus populations from Haikou City, Hainan Island, China. Infect Dis Poverty. 2016:5:31.

54. Hemingway J, Hawkes NJ, McCarroll L, Ranson H. The molecular basis of insecticide resistance in mosquitoes. Insect Biochem Mol Biol. 2004; 34(7):653-65.

55. Neng W, Yan X, Fuming H, Dazong C. Susceptibility of Aedes albopictus from China to insecticides, and mechanism of DDT resistance. J Am Mosq Control Assoc. 1992;8(4):394-7.

Submit your next manuscript to BioMed Central and we will help you at every step:

- We accept pre-submission inquiries

- Our selector tool helps you to find the most relevant journal

- We provide round the clock customer support

- Convenient online submission

- Thorough peer review

- Inclusion in PubMed and all major indexing services

- Maximum visibility for your research

Submit your manuscript at www.biomedcentral.com/submit
Biomed Central 